\title{
Ontogenetic and Structural Variation of Mineralizations and Ossifications in the Integument Within Ceratophryid Frogs (Anura, Ceratophryidae)
}

\author{
SILVIA QUINZIO* AND MARISSA FABREZI \\ Instituto de Bio y Geociencias-CONICET and Museo de Ciencias Naturales, Universidad \\ Nacional de Salta, Argentina
}

\begin{abstract}
Ceratophryidae represent a monophyletic group of terrestrial and aquatic frogs inhabiting lowlands of South America where they are more diverse in semiarid environments of the Chaco region. Adult morphology of ceratophryids presents some features associated to terrestrial and fossorial life such as hyper-ossified skulls, spade feet for digging, among others. For anurans, different mineralized structures have been described in the integument as calcium reservoirs and related to the terrestrial life and water balance (e.g., the calcified layer and dermal ossifications). We describe the ontogeny of the integument in the three genera of ceratophryids (Chacophrys, Ceratophrys, and Lepidobatrachus) that inhabit in semiarid environments. Data obtained demonstrated the early acquisition of metamorphic transformations in the integument layers in larvae of Ceratophrys cranwelli and Lepidobatrachus spp. and a continuous increment in the thickness of them up to old postmetamorphic stages. The integument of ceratophryids develops calcium deposits as the calcified layer during postmetamorphic stages. Furthermore, dorsal shields are also present in adult stages independently of terrestrial versus aquatic lifestyles. While the calcified layer seems to be a feature of a fully developed integument, in which their layers have acquired the adult thickness, dorsal shields develop at premetamorphic stages in L. llanensis and postmetamorphic individuals of $C$. cranwelli. In ceratophryids, similar to other studied taxa (e.g., Brachycephalus spp.) dorsal shields develop via an intramembranous ossification in which the calcified layer does not precede its differentiation. Within anurans, the occurrence of dorsal shields in the monophyletic ceratophryids suggested a distinctive evolutionary history in the lineage. Anat Rec, 295:2089-2103, 2012. (C) 2012 Wiley Periodicals, Inc.
\end{abstract}

\section{Key words: calcified layer; dorsal shields; Ceratophrys; Chacophrys; Lepidobatrachus}

\begin{abstract}
The integument of vertebrates is a continuous and heterogeneous cover formed by two layers; the epidermis and the dermis that are different in origin and structural organization (Dhouailly, 2009). This double-layered organization has particular features involving different functions for vertebrate lineages that provide important information for understanding their history, lifestyles, and relationships between organisms and the environment (Felsemburgh et al., 2006). In amphibians, the integument is unique among vertebrates due to its
\end{abstract}

Grant sponsor: Agencia Nacional de Promoción Científica y Tecnológica; Grant number: PICT-Bicentenario 0616.

*Correspondence to: Silvia Quinzio, Instituto de Bio y Geociencias-Consejo Nacional de, Investigaciones Científicas y Técnicas, Mendoza 2, 4400 Salta, República Argentina.

E-mail: silquinzio@gmail.com

Received 20 April 2012; Accepted 16 August 2012.

DOI 10.1002/ar.22601

Published online 16 Ocotber 2012 in Wiley Online Library (wileyonlinelibrary.com). 
higher permeability with functional consequences such as cutaneous respiration and osmoregulation (Bentley and Yorio, 1976). Furthermore, the presence of mineralization and ossifications associated with the integument has been described as a possible reservoir of calcium associated to water balance (Elkan, 1968; Bentley and Yorio, 1976; Sampson et al., 1987; Toledo and Jared, 1993; Stiffler, 1995; Azevedo et al., 2005; Witzmann et al., 2010).

The presence of calcium in the amphibian integument may be recognized in four types of morphological structures: dermal scales (Zylberberg and Wake, 1990; Castanet et al., 2003); the calcified layer (Elkan, 1968; Toledo and Jared, 1993; Azevedo et al., 2005); osteoderms (Ruibal and Shoemaker, 1984; Vickaryous and Sire, 2009); and dorsal shields (Trueb, 1973; Fabrezi, 2006; Campos et al., 2010).

Scales are only present in caecilians and are formed by mineralized collagen fibers hosted in the stratum spongiosum of the dermis. Bone is absent (Zylberberg and Wake, 1990; Castanet et al., 2003).

The calcified layer has been described in the skin of some frogs (Elkan, 1968). This layer, also known as Eberth-Kastschenko layer or fundamental layer is composed of glycosaminoglycans associated with calcium accumulations forming a thin sheet (continuous or distributed in patches) below the dermis (Elkan, 1968). Spatial and temporal variation has been described within and among species (Elkan, 1968; Toledo and Jared, 1993). The calcified layer has been recorded in species of Alytidae, Bufonidae, Ceratophryidae, Dendrobatidae, Hylidae, Leptodactylidae, Microhylidae, Pelobatidae, Rhacophoridae, and Ranidae (Elkan, 1968; Toledo and Jared, 1993; Azevedo et al., 2005; Fabrezi et al., 2010; Pelli et al., 2010). It was assumed that the calcified layer acts in water balance and protection against desiccation in terrestrial frogs as it has hydrophilic properties by the presence of glycosaminoglycans (Elkan, 1968; Toledo and Jared, 1993; Azevedo et al., 2005); further it is frequent in terrestrial taxa, absent in the aquatic pipids but some aquatic frogs such as Pseudis spp. and Barbourula busuangensis have calcified layer (Elkan, 1968; Fabrezi et al., 2010).

The term osteoderm names, in a broad sense, any ossification hosted in the dermis (Romer, 1956; Strahm and Schwartz, 1977; Zylberberg and Wake, 1990; O'Leary et al., 2004; Scheyer and Sander, 2004). Osteoderms vary greatly in size, shape, structure, ornamentation, and joints (Vickaryous and Hall, 2006). The osteoderms represent hard elements in which bone cells are immersed in an organic matrix which may combine premineralized bone, lamellar bone, or fibrolamellar bone associated with Sharpey's fibers (Vickaryous and Sire, 2009). The anuran osteoderms were described as small flattened elements (up to $3 \mathrm{~mm}$ ) immersed in the stratum spongiosum of the dorsal dermis of the head and trunk (Ruibal and Shoemaker, 1984). Osteoderms were recorded in Phyllomedusa bicolor, P. vaillanti, Gastrotheca weinlandii, Megophrys nasuta, Hylophractine augusti (Ruibal and Schoemaker, 1984), and Brachycephalus spp. (Campos et al., 2010). Although developmental data are not available for the osteoderms in amphibians, it was assumed that they are the result of metaplastic ossification that occurs by direct transformation of dermal cells in skeletal tissue in the absence of osteoblasts (Ruibal and Shoemaker, 1984; Zylberberg and Castanet, 1985; Zylberberg and Wake 1990; Scheyer and Sander, 2004; Vickaryous and Sire, 2009).

Dorsal shields are unusual among anurans (some dendrobatids, ceratophryids, and in Brachycephalus spp.) and they could be considered larger osteoderms (Trueb, 1973; Ruibal and Shoemacker, 1984; Vickaryous and Sire, 2009). Dorsal shields have been considered as special features of the integument (Moss, 1972; Ruibal and Shoemacker, 1984; Vickaryous and Sire, 2009) and related to terrestrial lifestyles (DeMar, 1966; Fabrezi, 2006; Clemente-Carvalho et al., 2009; Dilkes, 2009; Vickaryous and Sire, 2009; Campos et al., 2010). They are large bony plates (more than $5 \mathrm{~mm}$ in diameter) placed on, or fused to, the presacral vertebrae (Lynch, 1971; Trueb, 1973; Ruibal and Shoemaker, 1984; Fabrezi, 2006; Clemente-Carvalho et al., 2009; Campos et al., 2010).

The co-occurrence of the calcified layer and osteoderms in some frogs led to propose that this layer might represent the early stage of differentiation from which dermal skeletal structures develop (Ruibal and Shoemaker, 1984). Differently, Guardabassi (1963) interpreted the calcified layer as the vestiges of the dermal armor of primitive amphibians. Paleontological data recorded dorsal bony armors in different lineages of dissorophid temnospondyl of the Carboniferous and the Triassic (DeMar, 1966; Dilkes and Brown, 2007; Dilkes, 2009; Buchwitz and Voigt, 2010; Witzmann et al., 2010) which, together with other features (e.g., strong and hyperossified skeletons), suggested a scenario of terrestrial and semiarid conditions in which the thickening of the integument involved a minor loss of moisture through the skin (DeMar, 1966).

From these data, some generalizations emerge: (1) the integument of frogs may present a distinct calcified layer in the dermis; (2) the integument of frogs may present dorsal dermal ossifications immersed in the dermis; (3) the co-occurrence of both types of structures, in some taxa, could suggest that the calcified layer would be the initial stage of osteorderm development; and (4) both types of structures could represent vestiges of the extensive ossification (dermal armors) of the integument of primitive amphibians.

The Ceratophryidae Tschudi, 1838 are considered a distinctive group of neotropical frogs. Much has been discussed about the relationships of these genera but there is a strong consensus for the monophyly of the clade (see Reig and Limeses, 1963; Lynch, 1971; Laurent, 1986; Maxson and Ruibal, 1988; Haas, 2003; Fabrezi, 2006; Frost et al., 2006; Grant et al., 2006, Pyron and Wiens, 2011; among others). The clade is composed of the following taxa: Chacophrys Reig and Limeses, 1963 (one species), Lepidobatrachus Budgett, 1899 (three species), and Ceratophrys Wied-Neuwied, 1824 (eight species). Adults of Chacophrys and Ceratophrys are terrestrial, and adults of Lepidobatrachus are aquatic. Ceratophrys species are distributed in tropical areas of South America, and Ceratophrys cranwelli Barrio, 1980 and Ceratophrys ornata (Bell, 1843) are endemic to the Chaco region and sympatric with Lepidobatrachus species and Chacophrys pierottii (Vellard, 1948). As the Chaco region comprises semiarid environments with wet summers, these frogs are active during this season. In the Chaco, ceratophryids produce an 
epidermal cocoon during the dry season that reduces water loss and protects them until the next rainy season (Ruibal and Shoemaker, 1984; McClanahan et al., 1994).

Among the Ceratophryidae, dorsal shields are formed by a variable number of bony plates resting on the flattened neural spines of the presacral vertebrae; these shields are attached to the vertebral skeleton by ligaments (Fabrezi, 2006). Within ceratophryids, dorsal shields show a remarkable morphological and ontogenetic variation. In Ceratophrys, dorsal shields have been described in $C$. cranwelli, $C$. aurita, and $C$. ornata, and become differentiated at postmetamorphic stages (Lynch, 1971; 1982; Wild, 1997; Fabrezi, 2006). In these species, dorsal shields form a dorsal armor in which medial and lateral shields cover vertebrae II-VII and their transverse processes (Fabrezi, 2006). The number of shields is variable with three to five medial shields and three or more non-symmetric pairs of lateral shields. In Lepidobatrachus the shields are present in $L$. asper and $L$. llanensis with a smaller size and formed only by one or two shields of medial position which develop at larval stages in L. llanensis (Reig and Cei, 1963; Lynch, 1971; 1982; Fabrezi, 2006).

Consequently, the Ceratophryidae-being monophyletic, sharing similar habitats, and differing in lifestyles-represent an excellent model to explore the variation of the integument and test the generalizations mentioned above. For that, we present the study of morphological and histological variation in the integument during larval and adults stages and focus on mineralization and ossifications. We selected species of the three Ceratophryid genera living along the semiarid environments of the South American Chaco (C. pierottii, C. cranwelli, Lepidobatrachus asper, L. laevis and L. llanensis). Data about the presence/absence and timing of differentiation of the calcified layer and dorsal shields allow us to provide new information about the morphological variation to interpret the anuran evolution.

\section{MATERIALS AND METHODS}

Data in this study include descriptions of histological and anatomical variation during the ontogeny of the integument of C. pierottii, C. cranwelli, L. asper, L. laevis, and L. llanensis. Specimens (larvae and postmetamorphic stages) were collected in the field and were fixed in neutral-buffered formalin (4\%). Secretaria/ Ministerio de Medio Ambiente y Desarrollo Sustentable, Gobierno de la Provincia de Salta, República Argentina provided collecting permits from 2004 to 2009. We identified and selected ontogenetic series from Stages 35 to 46 following the standard Table of Gosner (1960) for $C$. pierottii and $C$. cranwelli and following Fabrezi and Quinzio (2008) for Lepidobatrachus spp. For larval series, we selected two or three specimens by stage and in the case of $L$. asper we use single specimens at Stages 35, 37, 44, 46, and adult. All specimens are deposited in the Herpetological Collection of the Museo de Ciencias Naturales (MCN), Universidad Nacional de Salta (Argentina), and listed in the Appendix except the specimens of $L$. asper which belong to the Colección Herpetológica del Laboratorio de Genética Evolutiva (LGE), Facultad de Ciencias Exacta y Naturales, Universidad Nacional de Misiones (Argentina).

Data were obtained from different sources:
1. Histological serial sections of larval and adult skin and shields; for histological sections of the skin we separated pieces of dorsal and ventral skin of premetamorphic, prometamophic, metamorphic, and postmetamorphic (adult) specimens of $L$. llanensis, $L$. llanensis, L. laevis, C. cranwelli, and C. pierottii. The skin pieces were dehydrated, embedded in paraffin, sectioned at $6 \mu \mathrm{m}$, and stained with hematoxylin-eosin. In specimens of L. llanensis and C. cranwelli, the dorsal shields were mechanically removed, decalcified in $5 \%$ nitric acid for about five days, dehydrated, embedded in paraffin, sectioned at $6 \mu \mathrm{m}$, and stained with hematoxylin-eosin. The histological techniques followed the protocol of Martoja and Martoja-Pierson (1970).

2. Skeletal whole-mounts of larval and adult specimens; we selected larval specimens of $L$. llanensis between Stages 37 and 46 and adult specimens of L. llanensis and $C$. cranwelli. These specimen were cleared and double-stained with Alizarin Red S and Alcian Blue to distinguish bone and cartilage, respectively (Wassersug, 1976).

3. Scanning electron microscopy of dorsal shields. Dorsal shields of adults that were fixed in neutral-buffered formalin $(4 \%)$ and preserved in alcohol $70^{\circ} \mathrm{C}$ of $\mathrm{L}$. llanensis and $C$. cranwelli were removed, macerated in soap, and cleaned with water and sodium hypochlorite, dehydrated and sputter-coated with gold following the protocols described in Bozzola and Russell (1999). The samples were analyzed under scanning electron microscope (SEM) at the LASEM (Laboratorio de Microscopía Electrónica de Barrido, ANPCyT/ UNSa/CONICET), Salta, Argentina.

Descriptions, illustrations, and photographs were made with a stereo microscope Nikon-SMZ1000 and light microscope Leica DM, equipped with an 8.1 megapixel Nikon Coolpix digital camera.

\section{Integument}

\section{RESULTS}

Tadpoles of ceratophryids at Stage 35 share an integument with the typical configuration described for most larval anurans with some inter-specific variation in the thickness of the different layers (Fig. 1A; Table 1). The skin has a two-layered epidermis, the inner layer with cuboidal cells and the outer layer with flattened cells. In the dermis only the stratum compactum is present and it is formed by lamellae of collagen fibers. Some melanocytes are seen (Fig. 1A, Table 1).

Development of larval integument implies the transformation of epidermal cells into adult type and the addition of epidermal layers from two to three or four layers in the ventral integument and to three to five layers in the dorsal integument, the development of glands, and the differentiation of the stratum spongiosum; these transformations occurs in a dorsal to ventral sequence (Fig. 1B-D; Table 1). By the end of larval development, when tail is completely lost, specimens of Ceratophryidae share general characteristics in the organization of the ventral and dorsal integument (e.g., pluristratified epidermis and two dermal strata already developed) although there is variation in the thickness 

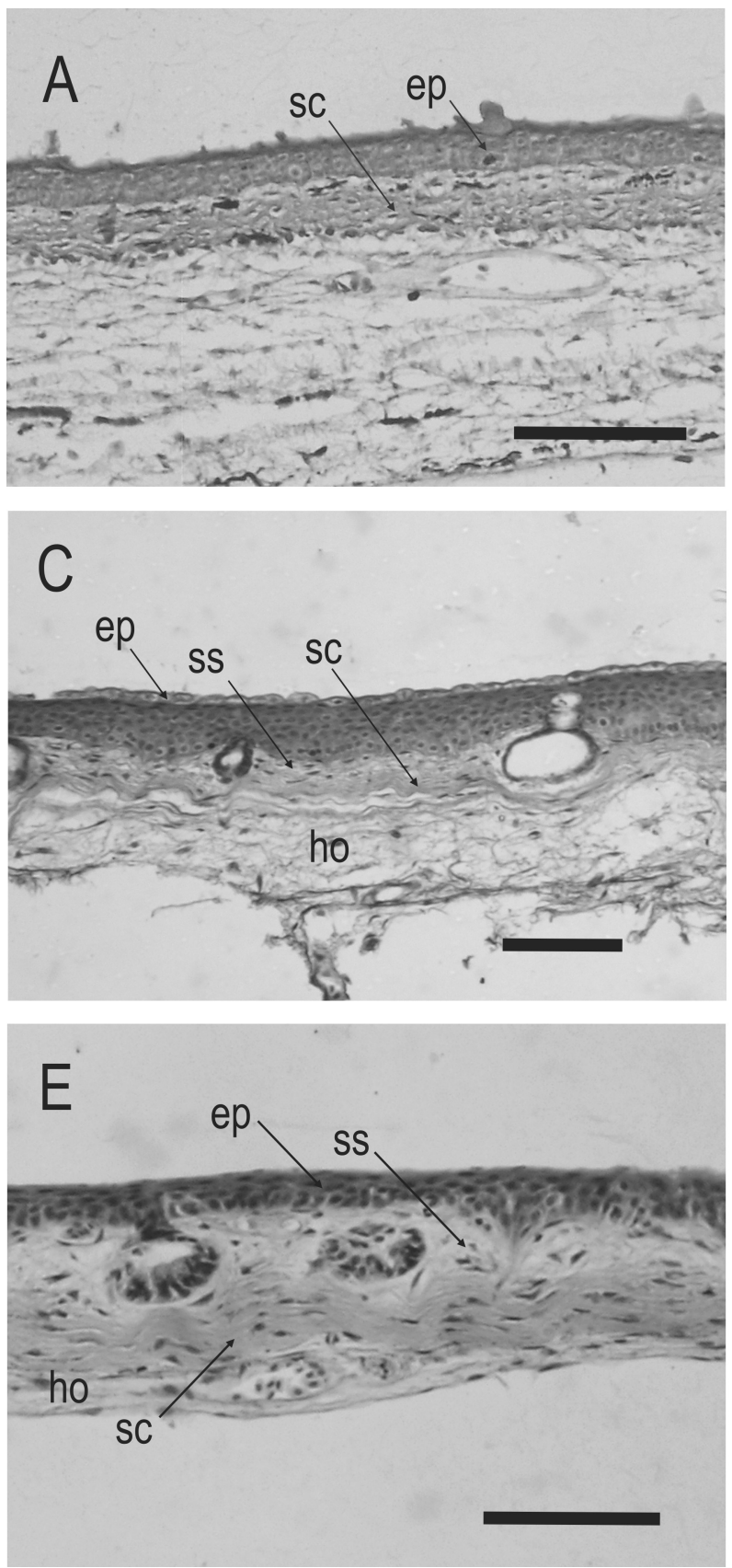

Fig. 1. Transverse sections of skin at different larval stages. A: Stage 35, Ceratophrys cranwelli dorsal skin. B-D: Stage 37. B: Chacophrys pierottii dorsal skin. C: Lepidobatrachus llanensis ventral skin. D: L. laevis dorsal skin. E, F: Stage 46. E: C. pierottii ventral skin. F:

of individual layers and the degree of their development (Fig. 1E,F; Table 1).

In adult stages (Fig. 2; Table 1), ceratophryids present a dorsal skin with a pluristratified epidermis with three to five layers of cells, the inner layers with cuboidal cells and the outer layer with flattened cells. For all species, the stratum spongiosum is thin but becomes thickened in those areas where mucous and serous glands are present. The melanocytes are distributed in a continuous layer beneath the basement lamella of the epidermis in
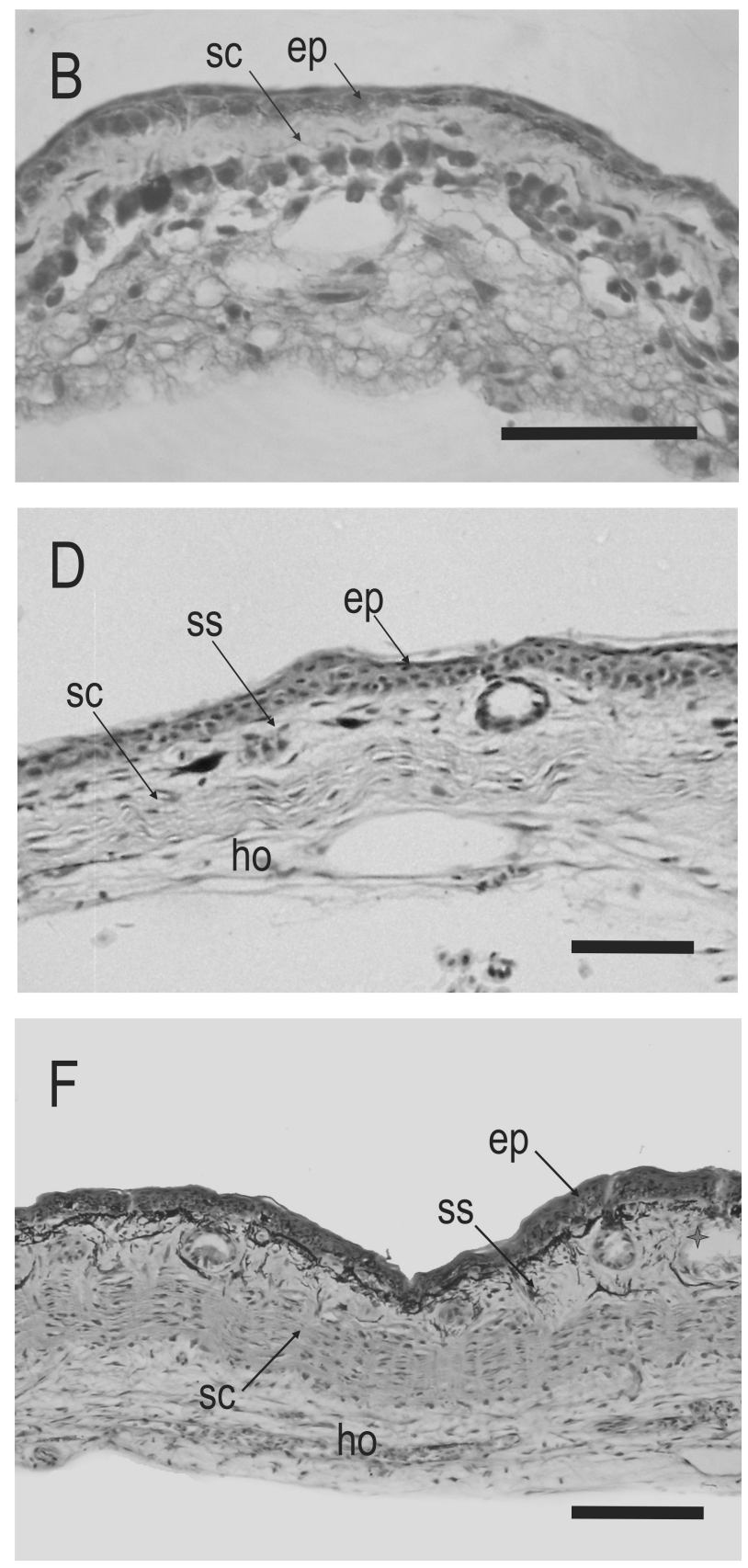

C. pierottii dorsal skin. Abbreviations: ep, epidermis; ho, hypodermis; sc, stratum compactum of the dermis; ss, stratum spongiosum of the dermis. Scale: (A,B) $50 \mu \mathrm{m},(\mathrm{C}-\mathrm{F}) 100 \mu \mathrm{m}$.

C. pierottii while in the other species melanocytes have a granular aspect with a discontinuous distribution. The calcified layer is always present and it is located between the stratum spongiosum and compactum of the dermis in all examined species. The calcified layer presents: (1) a continuous distribution, with an irregular thickness invading those areas without glands of the stratum spongiosum in $C$. pierottii or (2) a regular thickness and a discontinuous distribution in glandular areas in C. cranwelli, L. asper, L. laevis, and L. llanensis. In 
TABLE 1. Ontogenetic Variation of the Thickness (in $\mu \mathrm{m}$ ) of Larval and Adult Integument Layers and of their Mineralized Structures

\begin{tabular}{|c|c|c|c|c|c|}
\hline Ontogenetic stage and species & $\begin{array}{c}\text { Epidermis } \\
\text { dorsal }\end{array}$ & $\begin{array}{c}\text { Stratum } \\
\text { spongiosum } \\
\text { dorsal }\end{array}$ & $\begin{array}{c}\text { Calcified } \\
\text { layer } \\
\text { dorsal }\end{array}$ & $\begin{array}{c}\text { Stratum } \\
\text { compactum } \\
\text { dorsal }\end{array}$ & $\begin{array}{l}\text { Dorsal } \\
\text { shields }\end{array}$ \\
\hline Stage 35, Chacophrys pierottii & 10 & Absent & Absent & 15 & Absent \\
\hline Stage 35 , Ceratophrys cranwelli & 15 & Absent & Absent & 40 & Absent \\
\hline Stage 35 , Lepidobatrachus laevis & 25 & Absent & Absent & 50 & Absent \\
\hline Stage 35, L. llanensis & 10 & Absent & Absent & 40 & Absent \\
\hline
\end{tabular}

\begin{tabular}{|c|c|c|c|c|c|}
\hline $\begin{array}{l}\text { Ontogenetic } \\
\text { stage and species }\end{array}$ & $\begin{array}{c}\text { Epidermis } \\
\text { dorsal/ventral }\end{array}$ & $\begin{array}{c}\text { Stratum } \\
\text { spongiosum } \\
\text { dorsal/ventral }\end{array}$ & $\begin{array}{l}\text { Calcified layer } \\
\text { dorsal/ventral }\end{array}$ & $\begin{array}{c}\text { Stratum } \\
\text { compactum } \\
\text { dorsal/ventral }\end{array}$ & Dorsal shields \\
\hline Stage $37, C$. pierottii & $15 / 15$ & Absent & Absent & $20 / 10$ & Absent \\
\hline Stage $37, C$. cranwelli & $25 / 15$ & 15/Absent & Absent & $50 / 20$ & Absent \\
\hline Stage 37, L. laevis & $25 / 20$ & $10 / 10$ & Absent & $50 / 15$ & Absent \\
\hline Stage $37, L$. llanensis & $25 / 20$ & $30 / 10$ & Absent & $50 / 20$ & Present $150 \mu \mathrm{m}$ \\
\hline Stage $46, C$. pierottii & $20 / 20$ & $35 / 25$ & Absent & $75 / 35$ & Absent \\
\hline Stage $46, C$. cranwelli & $20 / 15$ & $35 / 25$ & Absent & $50 / 20$ & Absent \\
\hline Stage 46, L. laevis & $55 / 25$ & $40 / 40$ & Absent & $35 / 35$ & Absent \\
\hline Stage $46, L$. llanensis & $45 / 25$ & $35 / 35$ & Absent & $35 / 30$ & Present $350 \mu \mathrm{m}$ \\
\hline Adult, C. pierottii & $25 / 25$ & $60 / 25$ & $10 / 10$ & $125 / 175$ & Absent \\
\hline Adult, C. cranwelli & $30 / 50$ & $50 / 35$ & 15/Absent & $200 / 125$ & Present $800 \mu \mathrm{m}$ \\
\hline Adult, L. asper & 40/Absent & 50/Absent & 10/Absent & 120/Absent & Present \\
\hline Adult, L. laevis & $55 / 30$ & $75 / 50$ & $30 / 10$ & $210 / 100$ & Absent \\
\hline Adult, L. llanensis & $40 / 30$ & $70 / 40$ & $15 / 7.5$ & $230 / 100$ & Present $500 \mu \mathrm{m}$ \\
\hline
\end{tabular}

all species, the stratum compactum consists of compact layers of collagen fibers alternating with columns of collagen (Fig. 2B,D,F,H,I).

In the ventral integument the epidermis is pluristratified; in the dermis the stratum spongiosum is very thin and presents some discontinuous patches of melanocytes. The stratum compactum is formed by several lamellae and columns of collagen fibers arranged in alternating layers. Mucous and serous glands are partially immersed in this stratum in C. cranwelli and L. llanensis. The calcified layer is located between the strata spongiosum and compactum of the dermis with the exception of $C$. cranwelli in which the calcified layer is absent. The calcified layer in Lepidobatrachus spp. and $C$. pierottii is discontinuous and has an irregular thickness (Fig. 2A,C,E,G).

\section{Dorsal Shields}

Dorsal shields are absent in Lepidobatrachus laevis and Chacophrys pierottii. In L. asper and L. llanensis one or two small medial shields differentiate at premetamorphic larval stages (Fig. 3). In Ceratophrys cranwelli the differentiation of a variable number of medial and lateral shields that will join each other by ligaments (syndesmosis) occurs during juvenile stages (Fig. 4).

The dorsal shields in L. llanensis are anterior and posterior pieces, both of medial position. Shields fixed each other by connective tissue and their ventral surfaces are anchored by fibers to the flattened neural spines of the presacral vertebrae II-VI (Fig. 3B). Shape and size of the shields present variation during ontogeny. In metamorphic specimens, the anterior shield is triangular, longer, and covers the neural spines of the presacral vertebrae II-IV while the posterior one is rectangular and covers the neural spine of the vertebra V. The shields have rounded contours. In postmetamorphic specimens, both pieces form an oval-shaped complex, the anterior shield has grown laterally and the posterior one has grown lateral and caudally covering the neural spines of the vertebrae V and VI (Figs. 3 and 8). In adult specimens, the union of both shields has a diamond shape with the anterior shield as long as wide and the posterior shield longer than the anterior one which seems to grow in a posterior direction. The ventral surface of the shields is slight concave and smooth. The dorsal surface is covered with numerous spines projecting from the base of the plate and arranged in series of parallel rows (Fig. 3).

Scanning electron microscopy revealed the presence of pores of different diameters delimited by spines in the dorsal surface; larger pores are crossed by collagen fibers. In the ventral surface there are also some pores but they are fewer and do not penetrate the whole thickness of the bone (Fig. 3).

In $C$. cranwelli the number of shields composing the complex is variable, and they can be distinguished by their medial or lateral position (Fig. 4). The shields are irregularly shaped and vary in size; the smaller are arranged in the periphery and caudally. Shields contact each other through strong fibrous joints forming a semirigid complex covering the presacral vertebrae II-VIII and their transverse processes. The medial shields rest on the flattened neural spines of the vertebrae and the lateral shields on the transverse processes; the shields are attached to the vertebrae through fibers without being fused or co-ossified with them. Depending on the adult size [inferred from snout vent length (SVL) of specimens), there are seven (93.2 mm SVL), nine (85.14 $\mathrm{mm}$ SVL), and eleven (103.88 mm SVL) bony shields, with an irregular distribution of medial and lateral plates. The whole complex is oval shaped and it is wider than long; the ventral surface of each plate is smooth with few pores while the dorsal surface has numerous 

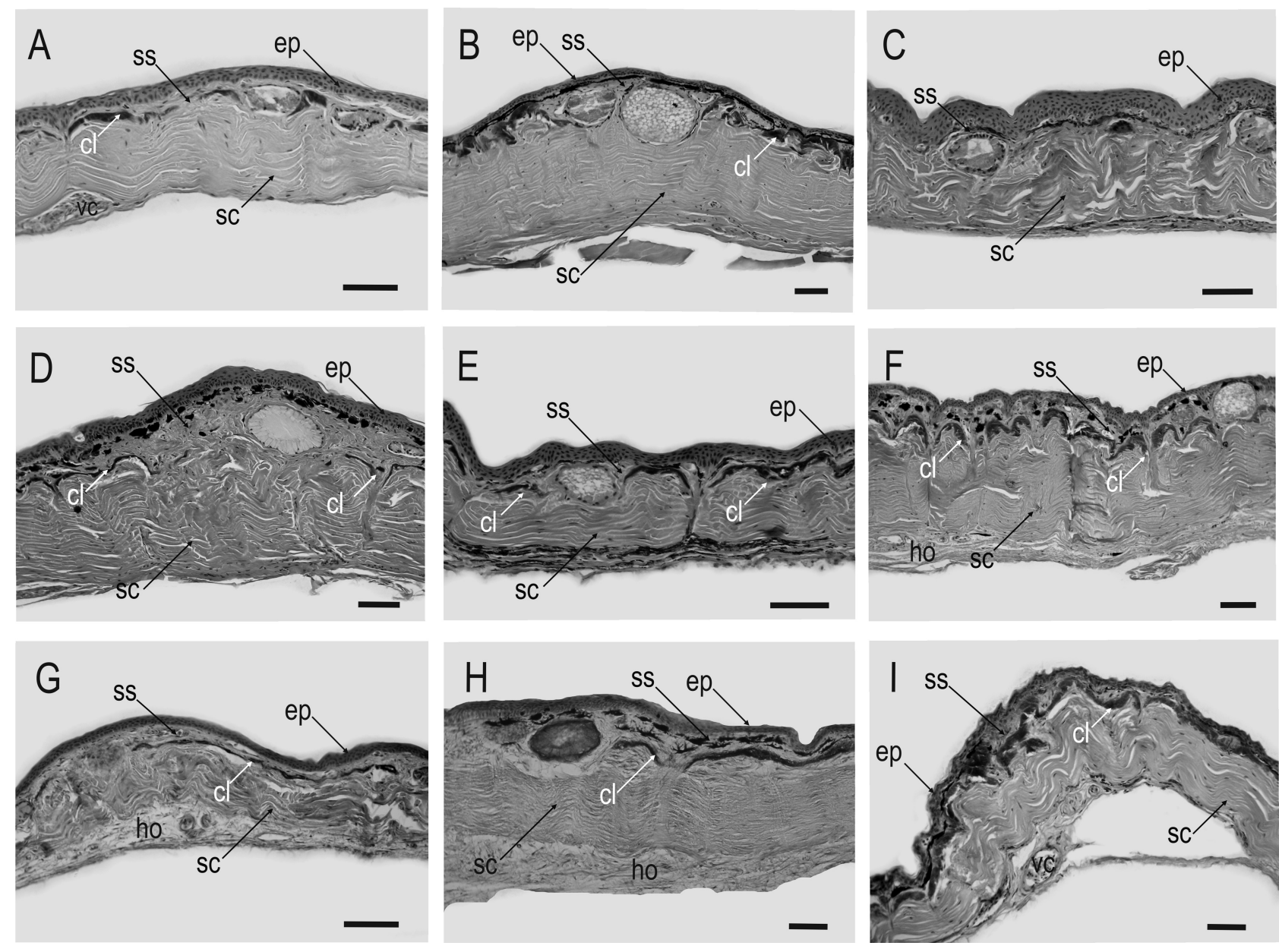

Fig. 2. Transverse sections of dorsal and ventral skin in adult stages. A: Chacophrys pierottii, ventral skin. B: C. pierottii, dorsal skin. C: Ceratophrys cranwelli, ventral skin. D: C. cranwelli, dorsal skin. E: Lepidobatrachus llanensis, ventral skin. F: L. llanensis, dorsal

skin. G: L. laevis, ventral skin. H: L. laevis, dorsal skin. I: L. asper, dorsal skin. Abbreviations: cl, calcified layer; ep, epidermis; ho, hypodermis; sc, stratum compactum of the dermis; ss, stratum spongiosum of the dermis. Scale: $100 \mu \mathrm{m}$.

bony spines arranged in a series of ridges. These spines develop as outgrowths of the dorsal surface of the osteodermal ossification. Spines are high with narrow bases surrounding pores which are crossed by collagen fibers (Fig. 4).

Histological analyses of dorsal shields in C. cranwelli and $L$. llanensis reveal a similar organization of the bone tissue in both species. In cross-sections, shields differ in thickness (Table 1). Shields are organized in an outer cortex on the dorsal surface, an inner cortex in the ventral surface, and a middle region composed of trabecular bone dominated by numerous large vascular cavities surrounded by thin lamellae of bone in a matrix containing osteocytes in lacunae arranged irregularly (Figs. 5A and 6A,B). This organization has been described as a diplöe structure. In L. llanensis, the middle region of the anterior shield has two main and medial cavities containing mesenchymal cells that cross the shield in rostrocaudal direction (Fig. 5B,C). Around these central cavities there are numerous smaller cavities with thin lamellar bone arranged at the periphery. The matrix of these lamellae contains numerous osteocytes in lacunae with irregular distribution (Fig. 5D).

The inner and outer cortexes of each shield consist of compact bone with irregularly distributed osteocytes in the lacunae. Also, some growth marks oriented parallel to the surface may be observed (Figs. $5 \mathrm{E}$ and $6 \mathrm{C}$ ). The dorsal surface of the outer cortex has an irregular contour defined by the apical growth of the bone which forms bony spines on the surface. In transverse sections, the stratum compactum of the dermis is interrupted due to the integration of its collagen fibers to the bone matrix; this integration seems to occur by the apical growth of the shield (Figs. 5E and 6C,D).

Differentiation of dorsal shields in L. llanensis begins at Stages 35 to 36 as an accumulation of mesenchymal cells embedded in the hypodermis above the neural arch of the vertebrae I and II (Fig. 7A,B). At larval Stage 37, these mesenchymal cells become differentiated and form a small and oval center; at this stage the cartilaginous neural arcs are not fused. In sections, the small ossification center is formed by thin trabecular bone which surrounds large vascular cavities (Fig. 7C,D). At Stage 38 , the trabeculae are thickened and present osteocytes in lacunae. At the periphery of the trabeculae there are numerous and ordered osteoblasts forming the 

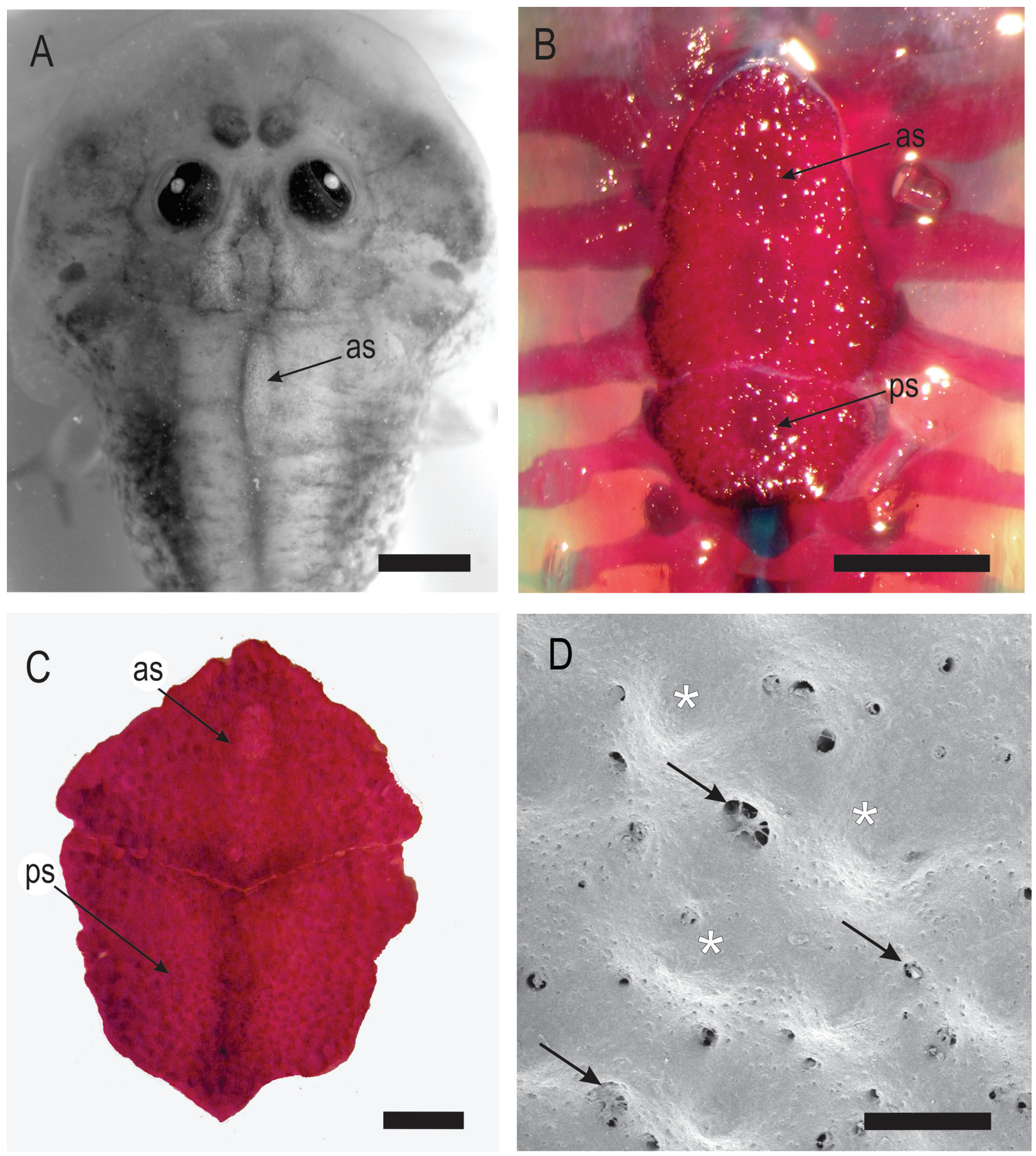

Fig. 3. Dorsal shields in Lepidobatrachus spp. A: L. asper tadpole at Stage 45 with a single shield. B: L. llanensis tadpole at Stage 46. The anterior and posterior shields are arranged over the flat neural spines of presacral vertebrae II-V. C: Dorsal shields of $L$. llanensis $(\mathrm{SVL}=78.48 \mathrm{~mm})$. D: Scanning electron microscopy of the dorsal sur-

periosteum while the apical growth of the ossification interrupts the compact layer of the dermis (Fig. 7E,F). Between Stages 39 and 41, two new ossifications differentiate posterior to the first one and over the presacral vertebrae III and V. As there is only a single posterior

face of the posterior shield of $L$. llanensis with lower bony spines (asterisks) and small depressions crossed by collagen fibers (black arrow). Abbreviations: as, anterior shield; ps, posterior shield. Scale: (A) $5 \mathrm{~mm}$, (B,C) $2 \mathrm{~mm}$, (E) $200 \mu \mathrm{m}$.

shield, these two plates will fuse or represent a single piece with a discontinuous mineralization (Figs. 7G,H and 8). During metamorphosis (Stages 42-46), the ossifications grow and expand dorsally and laterally; each shield is formed by trabecular bone, has a flat inner 

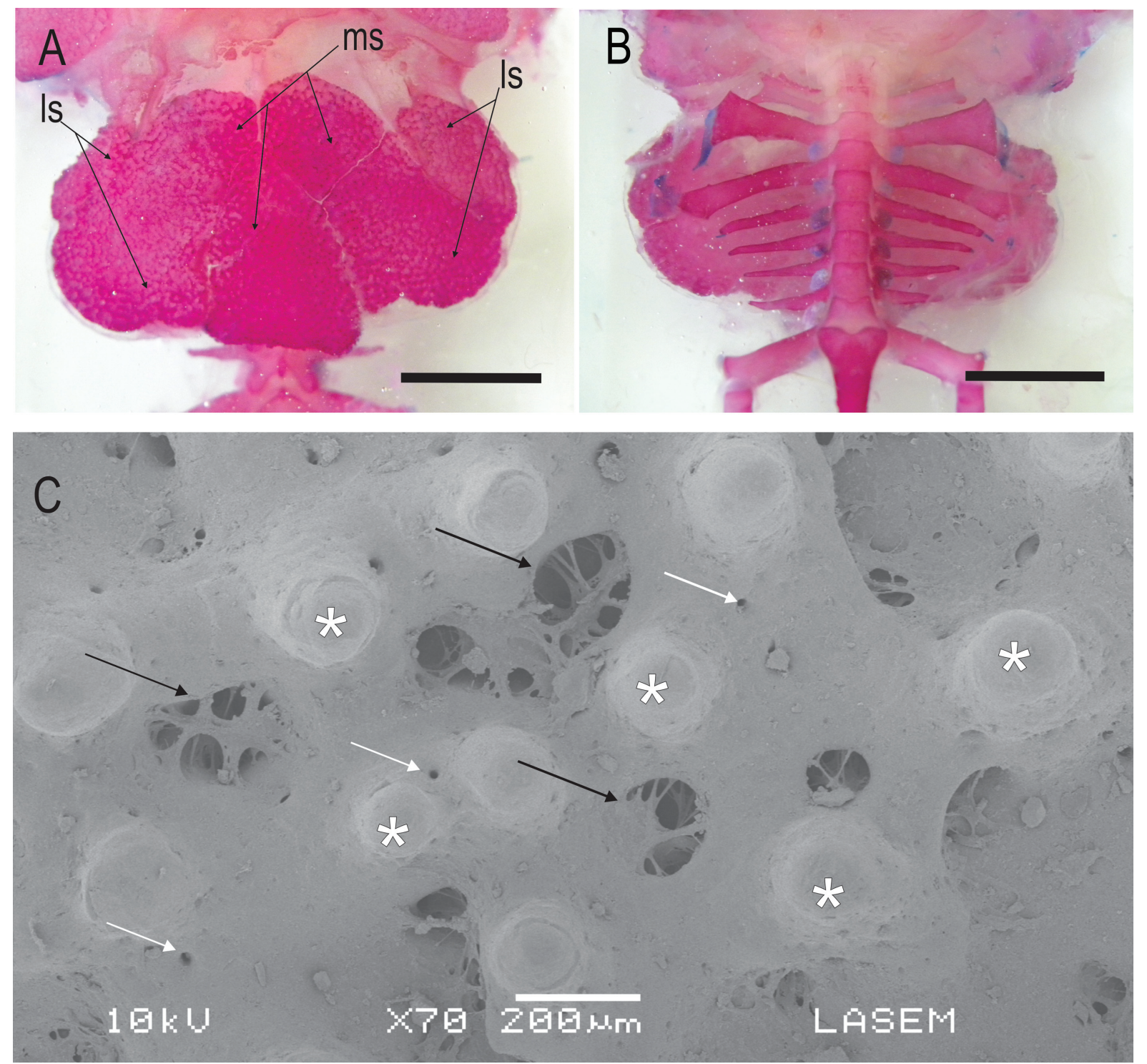

Fig. 4. Dorsal shields in Ceratophrys cranwelli. A: adult specimen $(S V L=93.20 \mathrm{~mm})$. Seven shields of irregular shapes. B: Ventral view of the armor presented in $(A)$, the armor completely covers the presacral vertebrae and its transverse processes. C: Scanning electron mi-

layer which rests on the neural arch of the corresponding vertebra, and extends laterally beyond it. On the dorsal surface, the apical growth of the ossification develops as spines and invades the stratum spongiosum (Fig. 7I,J). At the end of metamorphosis, the shield consists of two medial plates; the anterior covers the neural spines of the vertebrae II-IV and the posterior covers the neural spines of presacral vertebrae V (Fig. 8).

\section{DISCUSSION}

Metamorphic transformations from the larval to the adult integument in anurans imply changes associated from the aquatic larval life toward the terrestrial life of the adults. These transformations are generalized and described as events limited to the metamorphic stages croscopy photograph of the dorsal surface of a medial shield spines (asterisks); small pores (white arrow) and depressions crossed by collagen fibers (black arrow). Abbreviations: ms, medial shield; Is, lateral shield. Scale: (A-C) $10 \mathrm{~mm}$.

(Duellman and Trueb, 1986; Yoshizato, 1992; Tamakoshi et al., 1998; Brown and Cai, 2007).

In Ceratophryids, the changes that take place in the transformation from larval to adult integument (incremental number of epidermal layers, development of glands, and differentiation of two dermal strata) present variation in the timing of their occurrence. While in C. pierottii these transformations occur at metamorphic stages, like most anurans; in C. cranwelli, L. laevis, and L. llanensis they are pre-displaced to prometamorphic stages, like other larval features (Fabrezi and Quinzio, 2008) (Fig. 1). With differences in the temporal sequence of these transformations, ceratophryids share a dorsal to ventral sequence of changes which is evidenced by the earlier appearance of advanced characteristics in the dorsal skin (Fig. 1). In spite of the 

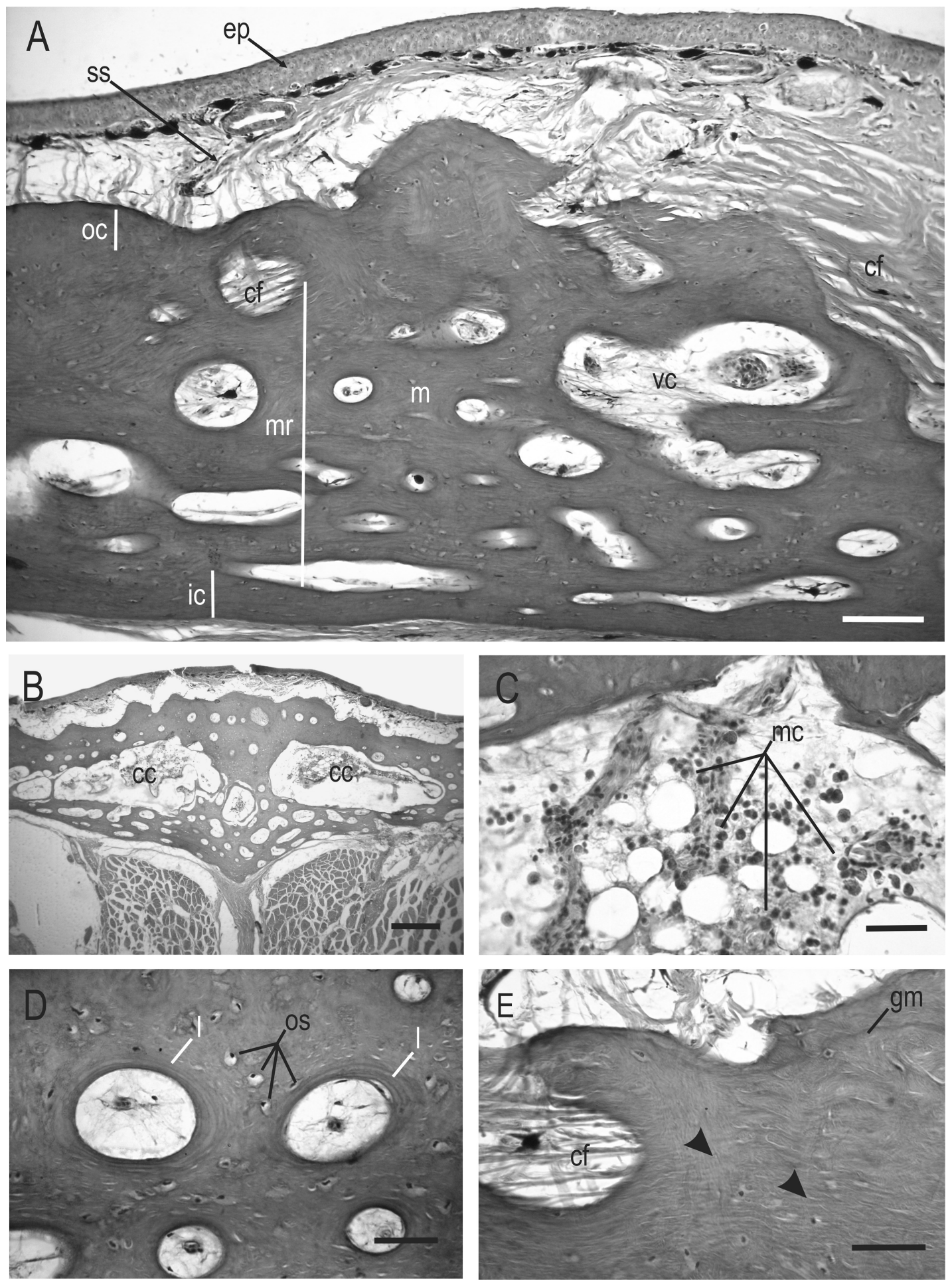

Fig. 5. Transverse section of the anterior dorsal shield in Lepidobatrachus llanensis. A: The diploë structure. B: Two principal vascular cavities. C: Detail of (B) showing the mesenchymal cells contained in the principal cavities. D: Bony matrix with numerous osteocytes in lacunae and bone lamellae around the periphery of the minor vascular cavities. E: Integration of collagen fibers of the dermis with the bony

matrix of the shield (black arrowhead). Abbreviations: cf, collagen fibers; ep, epidermis; gm, growth mark, ic, inner cortex; I, bone lamella; m, bony matrix; mc, mesenchymal cells; mr, middle region; oc, outer cortex; os, osteocytes; ss, stratum spongiosum of the dermis; vc, vascular cavities. Scale: (A,B) $200 \mu \mathrm{m}$; (C,E) $25 \mu \mathrm{m}$; (D) 100 $\mu \mathrm{m}$. 

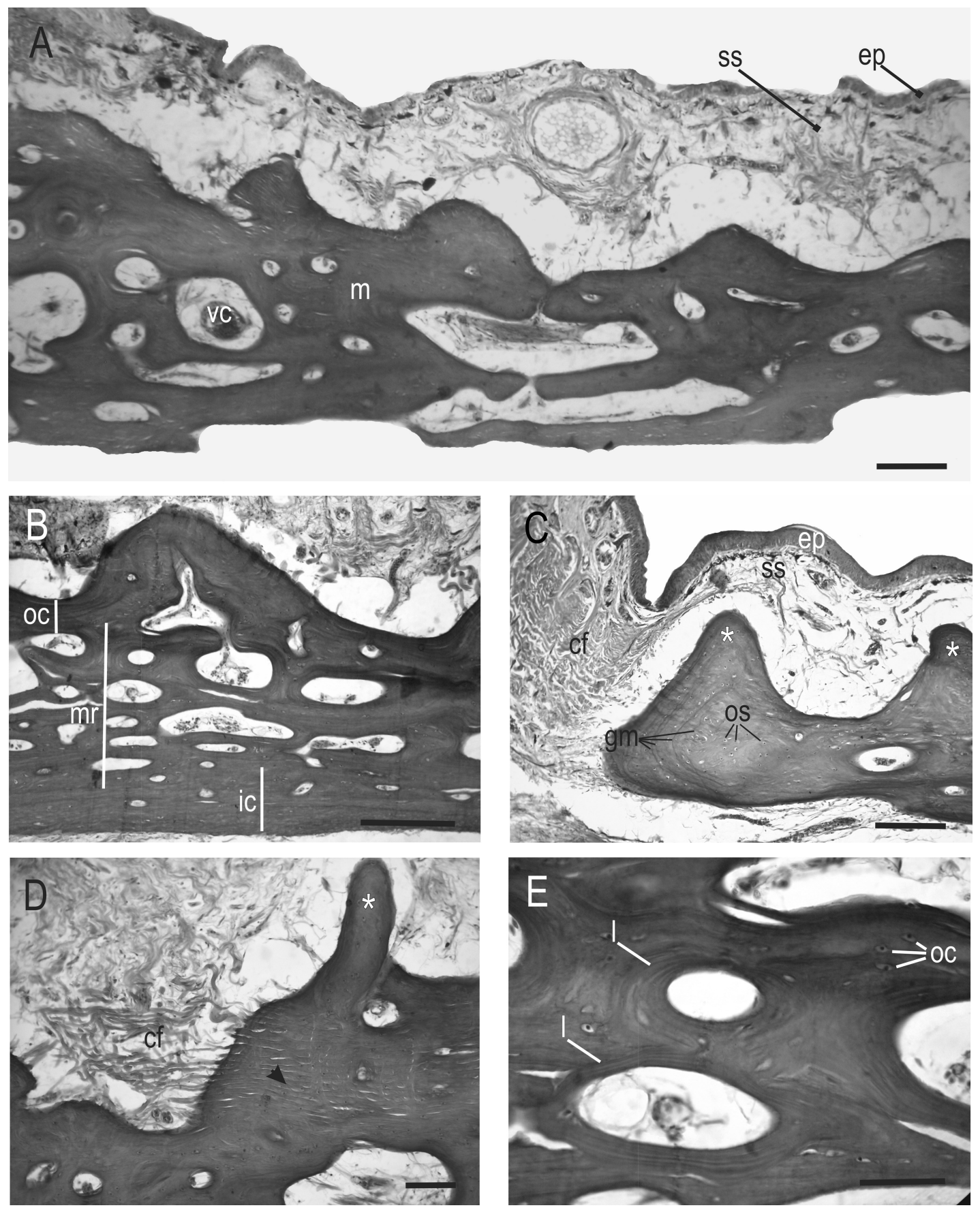

Fig. 6. Transverse section of a dorsal shield of lateral disposition in the armor of Ceratophrys cranwelli. A: Disposition of the dorsal shield below the stratum spongiosum. B: Diploë structure with numerous vascular cavities. C: Detail of the lateral end of the shield with numerous growth marks in its cortex. It can also be observed the apical growth of the shield forming bony spines (asterisks). D: Outer cortex of the shield in which the integration of the collagen fibers of the der-

mis with the bony matrix is distinguished. E: Bony matrix containing numerous osteocytes in lacunae and bone lamellae at the periphery of the vascular cavities. Abbreviations: cf, collagen fibers; ep, epidermis; growth mark, ic, inner cortex; I, bone lamella; m, bony matrix; mr, middle region; oc, outer cortex; os, osteocyte; ss, stratum spongiosum of the dermis; vc, vascular cavities. Scale: (A) $300 \mu \mathrm{m}$; (B-D) $200 \mu \mathrm{m}$; (E) $50 \mu \mathrm{m}$.

early acquisition of the complete structural configuration in the skin, the thickness of the different strata of the integument in Ceratophryids presents a continuous increment up to advanced postmetamorphic stages (Table 1).

The mineralized structures related to the adult integument in anurans (calcified layer and dorsal shields) also present variation in the timing of differentiation among ceratophryids. The calcified layer is present only in the adult integument, and while dorsal 

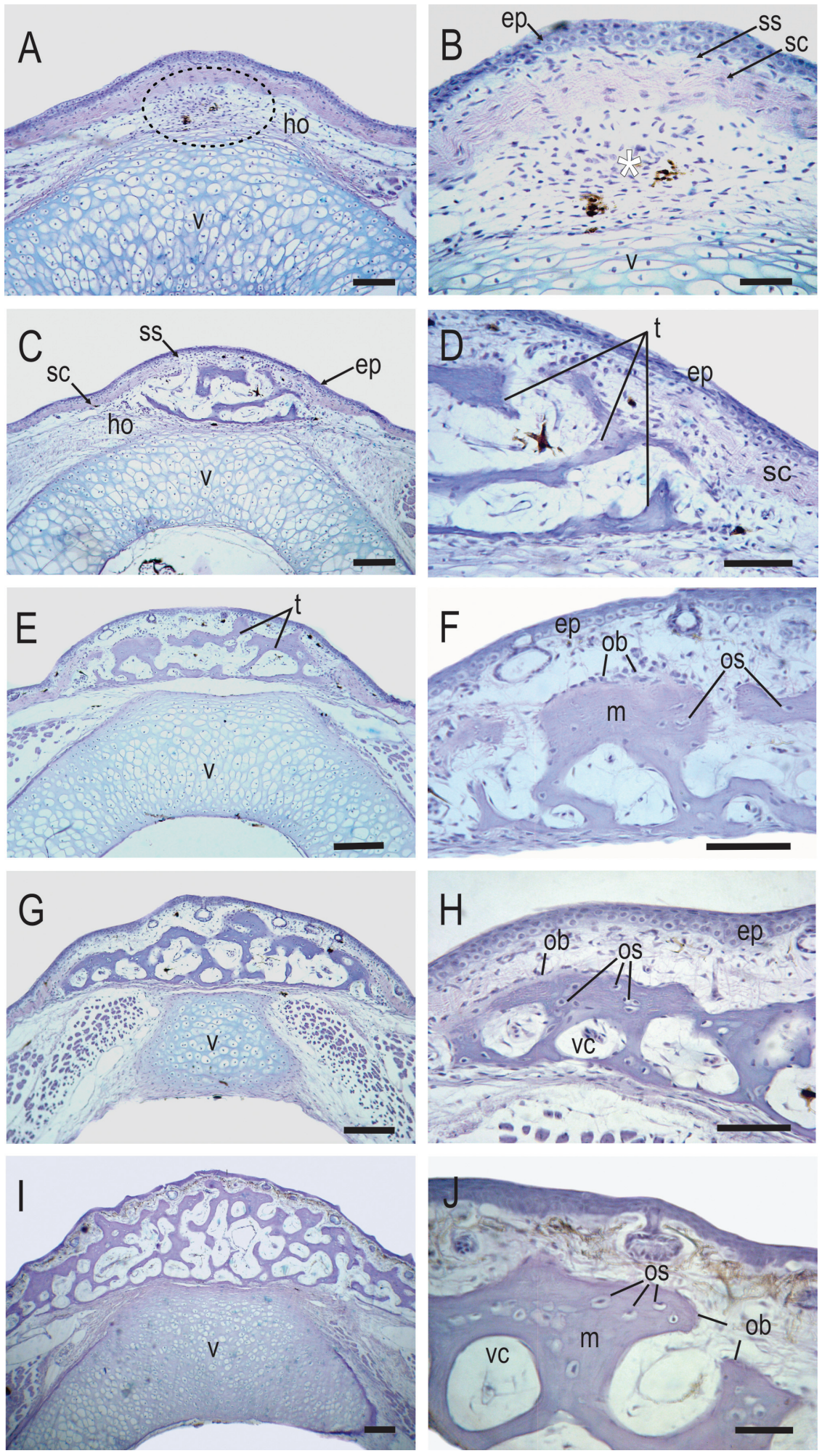

Fig. 7. Development of dorsal shields in Lepidobatrachus llanensis. A,B: Stage 36. A: Section of presacral vertebra I. Condensation of mesenchymal cells in the hypodermis. B: Detail of the mesenchymal cells (asterisk) in A. C,D: Stage 37. C: Differentiation of trabecular ossification. D: Detail of the ossification in (C). E,F: Stage 39. E: Trabeculae are thickened. F: Detail of trabeculae in (E). G,H: Stage 40. G: The apical growth of the ossification interrupts the stratum compactum. H: Detail of $(G)$.
Osteocytes are irregularly arranged in the matrix, vascular cavities contain some mesenchymal cells. I,J: Stage 46. I: The ossification acquires the diploë structure and small bony spines are already differentiated. J: Detail of (I). Abbreviations: ep, epidermis; ho, hypodermis; $\mathrm{m}$, bony matrix; ob, osteoblast, os, osteocyte; sc, stratum compactum of the dermis; ss, stratum spongiosum of the dermis; tb, trabeculae; $v$, vertebrae; vc, vascular cavities. Scale: (A,C,E,G,I) $100 \mu \mathrm{m} ;(B, D, F, H, I) 50 \mu \mathrm{m}$. 

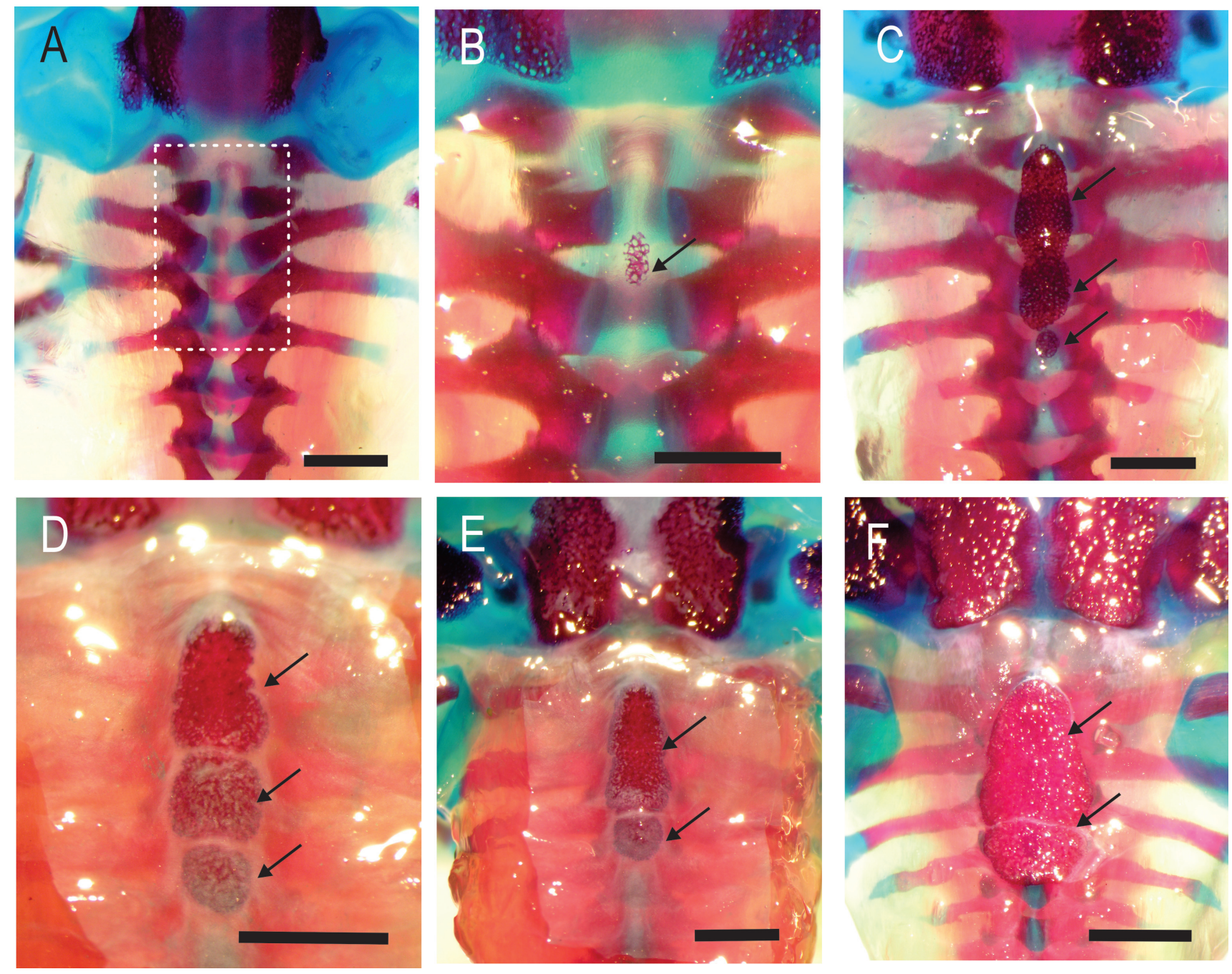

Fig. 8. Whole-mount skeletons of Lepidobatrachus llanensis larvae. A: Stage 36. Unfused and cartilaginous neural arches of vertebrae I-IV. Dashed box indicates where dorsal shields will develop. B: Stage 37. The calcified structure representing the anterior dorsal shield developed between vertebrae I and II. C: Stage 38. Two new calcified pieces

appear on vertebrae III and IV. D: Detail of dorsal shields in (C). E Stage 40. A single shield rests on vertebrae I-III. This shield represents two early fused pieces or a single one developed with a transversal unmineralized zone. F: Stage 45. G: Stage 46. Scale: (A, B) 1 mm; (C-F) $2.5 \mathrm{~mm}$.

shields develop at prometamorphic stages in L. llanensis its differentiation takes place in adult stages of C. cranwelli.

The calcified layer of the dermis has been described as a structure of frog skin whose absence in some aquatic taxa (Crinia signifera, in Myobatrachidae, Telmatobius, in Telmatobiidae; and Pipidae) led to propose that this layer is a feature of terrestrial anurans (Elkan, 1968; Toledo and Jared, 1993; Azevedo et al., 2005; Pelli et al., 2010). However, the calcified layer has been described in Barbourula busuangensis and in Pseudis spp. (Elkan, 1968) in which it is already completely differentiated at the end of the metamorphosis (Fabrezi et al., 2010). Furthermore, the aquatic Lepidobatrachus spp. also have calcified layer. Then, the calcified layer is present in certain aquatic species as well as it is absent in terrestrial taxa [e.g. Hyperolius spp., Rhinophrynus dorsalis, Limnodynastes dorsalis (Elkan, 1968)].

Different to those descriptions in Pseudis paradoxa (as P. platensis) presented by Fabrezi et al., (2010) and Quinzio (2011) in which the skin of the recently metamorphosed individual is identical to that of the adult, including the calcified layer, the calcified layer in ceratophryids differentiates during postmetamophic stages when the integument acquires the typical histological organization of the adult (Fig. 2; Table 1). Therefore, at least for the ceratophryids and $P$. paradoxa, the appearance of the calcified layer occurs when the integument has reached its final configuration.

Elkan (1968) suggested that this layer may be involved in the regulation of water balance due to the physiological properties of it components. This proposal is consistent with the presence of calcified layer for species that live in arid regions with high temperatures where the evaporation rate is high, such as the Chacoan terrestrial species of ceratophryids. However, it is also 
present in aquatic taxa (e.g. Lepidobatrachus spp. and $P$. paradoxa). Although other functions as mineral homeostasis, mechanical protection, or against desiccation (Elkan, 1968; Baldwin and Bentley, 1980; Toledo and Jared 1993; Azevedo et al. 2005; Lillywhite 2006) have been proposed for this layer, our findings do not provide arguments to discuss the function of the calcified layer.

Some authors proposed the co-occurrence of the calcified layer and ossifications in the dermis could represent that the calcified layer is the precursor site from which diverse ossifications develop in the skin (Ruibal and Shoemaker, 1984). From this generalization, the presence of the calcified layer should precede the differentiation of the shields but in L. llanensis dorsal shields appear before the calcified layer (Figs. 7 and 8). In $C$. cranwelli the calcified layer precedes the differentiation of the shields but it is absent in the area of the skin where the dorsal shield will develop. This fact could suggest that the calcified layer is replaced by the shields although the absence of the layer in the integument on the shields is also a feature of L. llanensis.

Development of dorsal shields by intramembranous ossification centers in an antero-posterior direction occurs during prometamorphic larval stages in Lepidobatrachus spp. without rigid link with presacral vertabrae (synchondrosis or synostosis) (Figs. 7 and 8). In $C$. cranwelli we could infer a sequential addition of ossification centers (beginning by the medial plates) that grow continuously in lateral and caudal directions. This suggestion is supported by the fact that specimens with higher SVL have more plates. Fabrezi and Quinzio (2008) staged individuals of $C$. cranwelli and found those larger than $75 \mathrm{~mm}$ reached 11 years by skeletochronology methods; this fact would suggested the differentiation of dorsal shields in C. cranwelli could occur when minimum size and age are achieved. Furthermore, specimens of $C$. cranwelli, $C$. ornata, and C. aurita smaller than $70 \mathrm{~mm}$ lack dorsal shields (Lynch, 1982; Ruibal and Shoemaker, 1984).

In Brachycephalus spp., dorsal shields are present and the calcified layer is absent on the skin of the shields (Ruibal and Shoemaker, 1984; Clemente-Carvalho et al., 2009; Campos et al., 2010). In Brachycephalus ephippium the development of dorsal shields occurs in a lateromedial sequence, from paravertebral shields (lateral shields in this study) to spinal shields (medial shields in this study) (Campos et al., 2010). In this species, the shields differentiate independently of the dermis as an intramembranous addition of osseous tissue derived from an osteo-chondrogenic membrane of the perichondry of the presacral vertebrae (Campos et al., 2010). Although ceratophryids and $B$. ephippium share the intramembranous development of dorsal shields they differ in the origin of the osteoblasts.

The amphibian osteoderms were defined as skeletal elements that develop by metaplasia (Ruibal and Shoemacker, 1984; Zylberberg and Wake, 1990); this definition was based on the histological organization of the adult osteoderm and differs from our findings in which the intramembranous ossification involves the normal differentiation of osteoblasts from mesenchymal cells of the hypodermis. The presence of osteoblasts during osteoderm development has also been described for turtles (Scheyer et al., 2008). Although the term osteoderm is used in tetrapods to identify any ossification related to the integument (Ruibal and Shoemacker, 1984; Zylberberg and Castanet, 1985; Zylberberg and Wake, 1990; Scheyer and Sander, 2004; Vickaryous and Hall, 2006; Vickaryous and Sire, 2009), developmental data are still scarce to provide a useful concept based on homology since dermal ossifications may involve diverse differentiation pathways (intramembranous, metaplastic ossification) and origins (hypodermis, perichondrial outgrowth).

The histological organization in diploë structure might indicate that osseous tissue grow faster in the early stages of development and gradually slow down (Witzmann and Soler-Gijón, 2010). This organization in Ceratophryids could also explain the presence of growth marks in the cortex of the shields.

The integration between the collagen fibers of the stratum compactum with the shield bone matrix (fibers seem to be engulfed by the apical growing of the external cortex of the shield) has similar features to those described for Sharpey's fibers whose function is related to give a strength but flexible attachment between dermal collagen fibers and skull co-ossifications in $B$. ephippium (Felisbino and Carvalho, 2000; Clemente-Carvalho et al., 2009; Witzmann and Soler-Gijón, 2010); and whose presence was observed in the inner surface of osteoderms in some amphibian temnospondyli [e.g., Gerrothorax and Peltobatrachus (Witzmann and SolerGijón, 2010)].

The temporal gap between the fossil amphibians and the origin of the anurans is too long to speculate about the homology of dorsal shields, as they were described in ceratophryids and Brachycephalus spp., with the osteoderms and dorsal armors of paleozoic amphibians. However, some structural resemblance may suggest an ancient and constrained capability of the tetrapod integument to generate mineralizations and ossifications.

In addition, the integument of ceratophryids presents calcium deposits as the calcified layer which develops at adult stages. Independently of this mineralized layer, some Ceratophryids bear dermal ossifications on their presacral vertebrae. These dorsal shields may appear before (Lepidobatrachus spp.) or after (Ceratophrys spp.) the metamorphosis, and vary in number, size, and shape to form a dorsal armor in Ceratophrys. Similar to other studied taxa (e.g., Brachycephalus spp.) calcium deposits and dermal ossifications in the adult skin have evolved in fossil amphibians but are rare among extant anurans. The presence of these calcified structures in the monophyletic lineage of ceratophryids suggested a distinctive evolutionary history.

\section{ACKNOWLEDGEMENT}

Authors are grateful to R. Bernal, F. Rodriguez, L. Quinzio, J. Goldberg, and S. Valdecantos for assistance in the field. J. Goldberg made valuable suggestions in an early draft of the manuscript. Authors thank two anonymous reviewers for their valuable comments and criticism which helped in improving the presentation; S. Blanco for providing technical assistance at the Laboratorio de Microscopía Electrónica de Barrido, Universidad Nacional de Salta; and Diego Baldo for the loan of Lepidobatrachus asper specimens. Secretaría de Medio Ambiente y Desarrollo Sustentable, Gobierno de la Provincia de Salta for permissions to collect the specimens of this study. 


\section{LITERATURE CITED}

Azevedo RA, Santana AS, Brito-Gitirana L. 2005. Dermal collagen organization in Bufo ictericus and in Rana catesbeiana integument (Anuran, Amphibian) under the evaluation of laser confocal microscopy. Micron 37:223-228.

Baldwin G, Bentley PJ. 1980. Calcium metabolism in bullfrog tadpoles (Rana catesbeiana). J Exp Biol 88:357-365.

Bentley PJ, Yorio T. 1976. The passive permeability of the skin of anuran Amphibia: a comparison of frogs (Rana pipiens) and toads (Bufo marinus). J Physiol 261:603-615.

Bozzola JJ, Russel LD. 1999. Electron microscopy. Principles and techniques for biologists. 2nd ed. Massachusetts: Jones and Bartlett Publishers.

Brown DD, Cai L. 2007. Amphibian metamorphosis. Dev Biol 306: 20-33.

Buchwitz M, Voigt S. 2010. Peculiar carapace structure of a Triassic chroniosuchian implies evolutionary shift in trunk flexibiliy. J Vert Paleontol 30:1697-1708.

Campos LA, Da Silva HR, Sebben A. 2010. Morphology and development of additional bony elements in the genus Brachycephalus (Anura: Brachycephalidae). Biol J Linn Soc 99:752-767.

Castanet J, Francillon-Vieillot de Ricqles H, Zylberberg A. 2003. The skeletal histology of the Amphibia. In: Heatwole H, Davies M, editors. Amphibian biology. Vol.5: Osteology. Chipping Norton, NSW: Surrey Beatty \& Sons. p1598-1683.

Clemente-Carvalho RBG, Antoniazzi MM, Jared C, Haddad CFB, Alves ACR, Rocha HS, Pereira GR, Oliveira DF, Lopes RT, dos Reis SF. 2009. Hyperossification in miniaturized toadlets of the genus Brachycephalus (Amphibia: Anura: Brachycephalidae): microscopic structure and macroscopic patterns of variation. J Morphol 270:1285-1295.

DeMar RE. 1966. The phylogenetic and functional implications of the armor of the Dissorophidae. Fieldiana Geol 16:55-88.

Dilkes D. 2009. Comparison and biomechanical interpretations of the vertebrae and osteoderms of Cacops aspideohorus and Dissorophus multicinctus (Temnospondyli, Dissorophidae). J Vert Paleontol 29:1013-1021.

Dilkes D, Brown LE. 2007. Biomechanics of the vertebrae and associated osteodermos of the Early Permian amphibian Cacops aspidephorus. J Zool 271:396-340.

Dhouailly D. 2009. A new scenario for the evolutionary origin of hair, feather, and avian scales. J Anat 214:587-606.

Duellman WE, Trueb L. 1986. Biology of amphibians. London: Johns Hopkins University Press.

Elkan E. 1968. Mucopolysaccharides in the anuran defence against desiccation. J Zool (Lond) 155:19-53.

Fabrezi M. 2006. Morphological evolution of Ceratophryinae (Anura, Neobatrachia). J Zool Syst Evol Res 44:153-166.

Fabrezi M, Quinzio SI. 2008. Morphological evolution in Ceratophryinae frogs (Anura, Neobatrachia): the effects of heterochronic changes during larval development and metamorphosis. Zool J Linn Soc 154:752-780.

Fabrezi M, Quinzio SI, Goldberg J. 2010. The ontogeny of Pseudis platensis (Anura, Hylidae): heterochrony and the effects of larval development on postmetamorphic life. J Morphol 271:496-510.

Felisbino SL, Carvalho HF. 2000. The osteochondral ligament: A fibrous attachment between bone and articular cartilage in Rana catesbeiana. Tissue Cell 32:527-456.

Felsemburgh FA, Carvalho-e-Silva SP, de Brito-Gitirana L. 2006. Morphological characterization of the anuran integument of the Proceratophrys and Odontophrynus genera (Amphibia, Anuran, Leptodactylidae). Micron 38:439-445.

Frost DR, Grant T, Faivovich J, Bain RH, Haas A, Haddad CBF, de Sá RO, Channing A, Wilkinson M, Donnellan SC, Raxworthy CJ, Campbell JA, Blotto BL, Moler P, Drewes RC, Nussbaum RA, Lynch JD, Green DM, Wheeler WC. 2006. The amphibian tree of life. Bull Am Mus Nat Hist 297:1-370.

Gosner K. 1960. A simplified table for staging anurans embryos and larvae, with notes on identification. Herpetologica 16:183-190.

Grant T, Frost DR, Cladwell JP, Gagliardo R, Haddad CBF, Kok PJR, Means DB, Noonan BP, Schargel WE, Wheeler WC. 2006.
Phylogenetic systematics of dart-poison frogs and their relatives (Amphibia: Athesphatanura: Dendrobatidae). Bull Am Mus Nat Hist 299:1-262.

Guardabassi A. 1963. Le caratteristiche citologiche, ultraestructurale, istochimiche e biochimiche di alcuni tessuti e organi che partecipano alla elaborazione di struture calcificate. Monit Zool Ital 70:1-55.

Haas A. 2003. Phylogeny of frogs as inferred from primarily larval characters (Amphibia: Anura). Cladistics 19:23-89.

Laurent RF. 1986. Souss classe lissamphibiens (Lissamphibia). Systématique. In: Grassé P, Delson M, editors. Traité de Zoologie. Anatomie, Systématique, Biologie. Tome XIV, Batraciens, Fasc. 1B Paris: Masson. p594-798.

Lillywhite HB. 2006. Water relations of tetrapod integument. J Exp Biol 209:202-226.

Lynch JD. 1971. Evolutionary relationships, osteology, and zoogeography of leptodactyloid frogs. Univ Kansas Mus Nat Hist Misc Publ 53:1-238.

Lynch JD. 1982. Relationships of the frogs of the genus Ceratophrys (Leptodactylidae) and their bearing on hypotheses of Pleistocene forest refugia in South America and punctuated equilibria. Syst Zool 31:166-179.

McClanahan LL, Ruibal RR, Shoemaker VH. 1994. Frogs and toads in deserts. Sci Am 270:82-88.

Martoja R, Martoja-Pierson M. 1970. Técnicas de histología Animal. Barcelona:Toray-Masson.

Maxson L, Ruibal RR. 1988. Relationships of frogs in the leptodactylid subfamily ceratophryinae. J Herpetol 22:228-231.

Moss M. 1972. The vertebrate dermis and the integumental skeleton. Am Zool 12:27-34.

O’Leary MA, Roberts EM, Head JJ, Sissoko F, Bouaré ML. 2004. Titanosaurian (Dinosauria: Sauropoda) remains from the 'continetal interclaire' of Mali. J Vert Paleontol 24:923-930.

Pelli AA, Cinelli LP, Souza Mourão PA, de Brito-Gitirana L. 2010. Glycosaminoglycans and glycoconjugates in the adult anuran integument (Lithobates catesbeianus). Micron 41:660-665.

Pyron RA, Wiens JJ. 2011. A large-scale phylogeny of Amphibia including over 2800 species, and a revised classification of extant frogs, salamanders, and caecilians. Mol Phyl Evol 61:543-583.

Quinzio SI. 2011. Evolución morfológica y desarrollo en Anuros: El sistema de la línea lateral y los escudos dorsales en Ceratophryinae (Anura, Ceratphryidae). Doctoral Thesis. Universidad Nacional de Tucumán, Argentina.

Reig OA, Cei JM. 1963. Elucidación morfológic-estadística de las entidades del género Lepidobatrachus Budget (Anura, Ceratophrynidae) con consideraciones sobre la extensión del distrito chaqueño del dominio zoogeográfico subtropical. Physis 67:181-204.

Reig OA, Limeses CE. 1963. Un Nuevo género de anuros ceratophrínidos del distrito chaqueño. Physis 24:113-128.

Romer AS. 1956. Osteology of the reptiles. Chicago: University of Chicago Press.

Ruibal R, Shoemaker V. 1984. Osteoderms in anurans. J Herpetol 18:313-328.

Sampson HW, Cannon S, Davis RW. 1987. The calcified amorphous layer of the skin of Bufo marinus (Amphibia: Anura). J Zool 213: $63-69$.

Scheyer TM, Brülmann B, Sanchez-Villagra MR. 2008. The ontogeny of the shell in side-necked turtles, with emphasis on the homologies of costal and neural bones. J Morphol 269:1008-1021.

Scheyer TM, Sander PM. 2004. Histology of ankylosaur osteoderms: implications for systematics and function. J Vert Paleontol 24: 874-893.

Stiffler D. 1995. Active calcium transportation in the skin of the frog Rana pipiens: kinematics and seasonal rhythms. J Exp Biol 198:967-974.

Strahm MH, Schwartz A. 1977. Osteoderms in the anguid lizard subfamily Diploglossinae and their taxonomic importance. Biotropica 9:58-72.

Tamakoshi T, Oofusa K, Yoshizato K. 1998. Visualization of the initiation and sequential expansion of the metamorphic conversion of anuran larval skin into the precursor of adult type. Dev Growth Differ 40:105-112. 
Toledo RC, Jared C. 1993. The calcified dermal layer in anurans. Comp Biochem Physiol A 104:443-448.

Trueb L. 1973. Bones, frogs, and evolution. In: Vial JL, editor. Evolutionary biology of the Anurans: contemporary research on major problems. Columbia: University of Missouri Press. p65-132.

Vellard J. 1948. Batracios del Chaco argentino. Acta zool Lilloana 5: 137-174.

Vickaryous MK, Hall BK. 2006. Osteoderm morphology and development in the nine-banded armadillo, Dasypus novemcinctus (Mammalia, Xenarthra, Cingulata). J Morphol 267:1273-1283.

Vickaryous MK, Sire J. 2009. The integumentary skeleton of tetrapods: origin, evolution, and development. J Anat 214:441-464.

Wassersug RJ. 1976. A procedure for differential staining of cartilage and bone in whole formalin fixed vertebrates. Stain Technol 51:131-134.

Wild ER. 1997. Description of the adult skeleton and developmental osteology of the hyperossified horned frog, Ceratophrys cornuta (Anura: Leptodactylidae). J Morphol 232:169-206.

Witzmann F, Scholz H, Müller J, Kardjilov N. 2010. Sculpture and vascularization of dermal bones, and the implications for the physiology of basal tetrapods. Zool J Linn Soc Lon 160:302-340.

Witzmann F, Soler-Gijón R. 2010. The bone histology of osteoderms in temnospondyl amphibians and in the chroniosuchian Bystrowiella. Acta Zool 91:96-114.

Yoshizato K. 1992. Death and transformation of larval cells during metamorphosis of anura. Dev Growth Differ 34:607-612.

Zylberberg L, Castanet J. 1985. New data on the structure and growth of the osteoderms in the reptile Anguis fragilis (Anguidae, Squamata). J Morphol 186:327-342.

Zylberberg L, Wake MH. 1990. Structure of the scales of Dermophis and Microcaecilia (Amphibia: Gymnophiona) and a comparison to dermal ossifications of other vertebrates. J Morphol 206:25-43.

\section{APPENDIX}

\section{Abbreviations of Museums}

MCN: Museo de Ciencias Naturales, Universidad Nacional de Salta, Argentina.

LGE: Laboratorio de Genética Evolutiva, Facultad de Ciencias Exacta y Naturales de la Universidad Nacional de Misiones, Argentina.

\section{Ceratophryidae}

Ceratophrys cranwelli: MCN 425, MCN 427 (larval specimens Stages 35-46) skin cross sections; MCN (one adult) skin cross sections and scanning electron microscopy; MCN 188, MCN 260, MCN 206 (adults), skeleton whole mounts.

Chacophrys pierottii: MCN 1027, MCN 1028, MCN, 1029 (larval specimens Stages 35-46) skin cross sections; MCN 987 (one adult) skin cross sections.

Lepidobatrachus laevis: MCN 814, MCN 1109 (larval specimens Stages 35-46) skin cross sections; MCN 815 (one adult) skin cross sections.

Lepidobatrachus llanensis: MCN 1118, MCN 1122 (larval specimens Stages 35-46) skin cross sections and skeleton whole mounts; MCN 081 (one adult) skin cross sections and scanning electron microscopy; MCN 986, MCN 667 (two adults) skeleton whole mounts.

Lepidobatrachus asper: LGE 328 (larval specimens Stages 35, 37, 44, 46) skin cross sections; LGE 102 (one adult) skin cross sections. 